\title{
Phenolic profile of some fruit wines and their antioxidant properties
}

\author{
Uroš D. Čakar ${ }^{1}$, Aleksandar V. Petrović ${ }^{2}$, Marijana B. Živković ${ }^{3}$, Vlatka E. Vajs ${ }^{3}$, Miodrag M. Milovanović ${ }^{4}$, \\ Jiri Zeravik ${ }^{5}$, Brižita I. Đorđević ${ }^{1}$ \\ ${ }^{1}$ University of Belgrade, Faculty of Pharmacy, Belgrade, Serbia \\ ${ }^{2}$ University of Belgrade, Faculty of Agriculture, Belgrade-Zemun, Serbia \\ ${ }^{3}$ University of Belgrade, Institute of Chemistry Technology and Metallurgy, Belgrade, Serbia \\ ${ }^{4}$ Masaryk University, Faculty of Science, Brno, Czech Republic \\ ${ }^{5}$ Masaryk University, CEITEC - Central European Institute of Technology, Brno, Czech Republic
}

\begin{abstract}
The composition and content of individual phenolic compounds in various fruit wines and overall antioxidant properties of these fruit wines were studied. Phenolic compounds were separated by reverse phase (RP) HPLC techniques, and their content was determined by means of mass spectrometer (MS) with triple quadrupole (TQ) analyser, which recorded specific precursor-product transitions. Antioxidant activity was monitored by the following spectrophotometric methods: DPPH, FRAP and Folin-Ciocalteu assay, respectively. Four types of berries (raspberry, blackberry, chokeberry and blueberry), one type of pome (apple) and one type of stone fruit (cherries) were used for the production of fruit wines. Corresponding fruit wines were produced by microvinification with or without adding sugar into the must before fermentation. Increase in alcohol level was responsible for the increased content of phenolic compounds in fruit wine due to improved extraction conditions. Produced fruit wines were preserved by adding $\mathrm{SO}_{2}$ which interferes with the determination of antioxidant activity of phenolic compounds. In this case, the development of a correlation method based on FRAP assay was introduced. Fruit wines are a rich source of substances which show beneficial effects on human health. Depending on the fruit type, different antioxidant compounds were predominant in wine samples.
\end{abstract}

Keywords: fruit wines, phenolic compounds, antioxidant activity, DPPH, FRAP, HPLC-MS/MS.

\author{
SCIENTIFIC PAPER \\ UDC 663.3:547.9:66:543.544 \\ Hem. Ind. 70 (6) 661-672 (2016) \\ doi: 10.2298/HEMIND150722002C
}

Available online at the Journal website: http://www.ache.org.rs/HI/

Fruits and vegetables are a rich source of compounds exhibiting beneficial effects on human health. One of the most interesting compounds for researchers today are dietary polyphenols [1]. The diet with high intake of food rich in phenolic compounds is associated with a lower risk of heart diseases. It can be seen from the fact that phenolic compounds slow down the progression of atherosclerosis by protecting low density lipoproteins (LDL) from oxidation [2]. Wine is a rich source of compounds which exhibit beneficial effects on human health, with polyphenols as the most important. Active ingredients from grape seed, procyanidins and proanthocyanidins, are used in medicinal products for the treatment of circulatory disorders such as capillary fragility and microangiopathy of the retina. Procyanidins and proanthocyanidins showed antioxidant plasma activity, reduction of platelet aggregation and increase in the resistance of healthy cells to toxicants and carcinogenic agents [3]. The latest studies on biological activity have focused mainly on wines made

Correspondence: U.D. Čakar, University of Belgrade, Faculty of Pharmacy, Vojvode Stepe 450, 11000 Belgrade, Serbia.

E-mail: urosc@pharmacy.bg.ac.rs; uroslion@gmail.com

Paper received: 22 July, 2015

Paper accepted: 24 December, 2015 from red grape varieties and particularly emphasized trans-resveratrol [4].

It is well known that wine can be made from various types of fruit. There are just a few papers reporting on biological activity of wine made from fruit. While it is true that fruit wines are being increasingly consumed, they are underestimated by scientific research for no valid reason. A couple of studies have shown that fruit wines are a rich source of phenolic compounds capable of demonstrating antioxidant properties in vivo $[5,6]$ and significantly decreasing the risk of cardiovascular diseases [7].

In the production process of berry and fruit wines, pressed juice is obtained from apples, pears, cherries, plums, peaches, red currants, gooseberries, bilberries, cranberries, raspberries, hip berries and rhubarb. Industrial production of berry and fruit wines exists in many countries. A well-known product is apple wine (cider) which is common in France, the United Kingdom and the United States. Besides cider, pear wine known as "poire" is also produced in France [8]. South Korea has a long tradition of making wine from raspberries $[9,10]$ and plums [11]. The process of berry and fruit wine-making is the same as making wine from grapes. In general, berry or fruit mash is first pressed and then the pressed juice undergoes fermentation [5]. The fact 
which encourages producers of fruit wines is that global annual fruit production in 1996 amounted to 469 million $\mathrm{t}$ and it continues to grow every year at the average rate of $1.6 \%$ [12].

Antioxidant properties of commercial fruit wines have been investigated in recent times. The wines in these studies were made mostly from just a few kinds of fruit. The aim of our study was to produce wine from different kinds of fruit in the controlled conditions of microvinification and to determine physicochemical parameters, antioxidant properties and quantitative content of specific phenolic compounds.

\section{MATERIALS AND METHODS}

\section{Plant material}

Raspberry fruit (Rubus idaeus), cultivar Meeker, was obtained from commercial orchards in the region of Valjevo, Serbia. Blackberry fruit (Rubus sp.), cultivar Čačak Thornless, was obtained from commercial orchards in the region of Bojnik, Serbia. Black chokeberry fruit (Aronia melanocarpa, Heynh.) was obtained from commercial orchards in the region of Suvobor Mountain, Serbia. Apple fruit (Malus domestica, Borkh.), cultivar Jonagold, and sour cherry (Prunus cerasus L.), cultivar Čačanski rubin, was obtained from commercial orchards in the region of Grocka, Serbia. Wild blueberry fruit (Vaccinium myrtilus) was obtained from the region of mountain Durmitor, Montenegro.

\section{Vinification}

Wines were made through microvinification from two kinds of bramble fruit (raspberry and blackberry), two kinds of berry fruit (blueberry and black chokeberry), one kind of pomaceous fruit (apple) and one kind of fruit from the drupe family (sour cherry). The fruit was picked in 2013, in the state of full technological maturity and phytosanitary health of $100 \% .30$ $\mathrm{kg}$ of each fruit was used in microvinification during 2013. Before fermentation, sour cherry was processed by two techniques. In the first method, the pits were removed from the fruit before it was fragmented, while in the second method, the fruit was fragmented together with the pits but without cracking them. Brambles, berries, cherries and apples were fragmented and, as with some other authors [13], $\mathrm{K}_{2} \mathrm{~S}_{2} \mathrm{O}_{5}$ was added in the must to inhibit growth of unwanted bacterial populations during fermentation. $10 \mathrm{~g}$ of potassium metabisulfite $\left(\mathrm{K}_{2} \mathrm{~S}_{2} \mathrm{O}_{5}\right) / 100 \mathrm{~kg}$ was added to the obtained pomace. Subsequently, the pomace was inoculated with the pure strain of selected wine yeast Lievito Secco (Enartis, Italy) at the dose of $20 \mathrm{~g} / 100 \mathrm{~kg}$. This is how the control samples were prepared. Another sequence of experiments was performed using the fruit processed in the same way but with sugar - sucrose (Šajkaška, Serbia) added directly to the pomace in order to increase total soluble solids in the must up to $20.5^{\circ}$ Brix. Adding this amount of sugar before fermentation was intended to achieve alcohol content of $11 \%$ in the end product. Alcohol fermentation of each investigated fruit pomace was carried out at room temperature $\left(20^{\circ} \mathrm{C}\right)$ over the next 7 to 10 days. While undergoing fermentation, the pomace was regularly stirred twice a day. Once the fermentation was completed, young wine was separated by straining without pressure. Wine yield was from 45 to $60 \%$ for raspberry, blackberry, blueberry and black chokeberry, while it was $50 \%$ for the cherry and around $60 \%$ for the apple. After one month, the wine was racked off the sediment for the first time and the racking was repeated the following month. The wines were kept at $8{ }^{\circ} \mathrm{C}$ during the next six months and after that time all analyses were performed. The wines made that way were further stabilized by keeping them in a cold place. Once stabilized, the wine samples were prepared for analysis.

\section{Physicochemical characterization of wine samples}

A microprocessor-based $\mathrm{pH} / \mathrm{mV} /{ }^{\circ} \mathrm{C} \mathrm{pH} 212$ (Hanna instruments, Woonsocket, RI, USA) was used for $\mathrm{pH}$ determination. Total titratable acidity (TTA) of fruit wine samples was determined by titrating $25 \mathrm{~mL}$ of wine sample with $0.25 \mathrm{M}$ of $\mathrm{NaOH}$ solution using a $\mathrm{pH}$ meter and phenolphthalein as an indicator of titration endpoint. TTA results were expressed in $\mathrm{g} / \mathrm{L}$ of malic acid. Total soluble solids (TTS) were measured in the must by using the refractometer PAL-87S (Atago, Tokyo, Japan) and the results were expressed in ${ }^{\circ}$ Brix. Alcohol concentration was determined by using an alcohol density meter DMA 35 (Anton Paar, Graz, Austria) after distillation of wine samples. From the obtained density of alcoholic distillate, strength by volume (vol.\%) was obtained by using $20^{\circ} \mathrm{C} / 20^{\circ} \mathrm{C}$ tables [14].

\section{Standards and reagents}

All chemicals and reagents were of analytical grade. Standards of kaempferol, sinapic acid, gallic acid, chlorogenic acid, vanillic acid, caffeic acid and $p$-coumaric acid were purchased from Sigma Aldrich (Steinheim, Germany). Standards of epicatechin, protocatechuic acid, $p$-hydroxybenzoic acid, catechin, rutin, ellagic acid, naringenin and quercetin were purchased from Fluka AG (Buch, Switzerland). The other compounds 2,2-diphenyl-1-picrylhydrazyl (DPPH), 2,4,6-tripyridyl-s-triazine (TPTZ), acetonitrile (HPLC grade) were supplied by Sigma Aldrich (Steinheim, Germany). Methanol, which was used to make solutions from standards, was purchased from Merck (Darmstadt, Germany). Folin-Ciocalteu reagent and formic acid were purchased from Merck (Darmstadt, Germany). Ultrapure water (TKA Germany MicroPure water purification system, $0.055 \mu \mathrm{S} / \mathrm{cm}$ ) was used to prepare standard 
solutions and dilutions. The Premium Syringe Filters (Captiva) Regenerated Cellulose $0.45 \mu \mathrm{m}, 15 \mathrm{~mm}$ were purchased from Agilent Technologies (Santa Clara, CA, USA).

\section{HPLC analysis}

Wine samples were first filtered through premium syringe filter (Captiva) regenerated cellulose $0.45 \mu \mathrm{m}$, $15 \mathrm{~mm}$ (Agilent Technologies). The analysis of phenolic compounds in wine was carried out using a Waters Acquity UPLC H-Class (WAT-176015007) (Milford, MA, USA) equipped with quaternary pump (Waters Quaternary Solvent Manager), injector (Waters Sample Manager-FTN (Flow Through Needle)), column compartment with ZORBAX Eclipse XDB C18 column (150 mm $\times 4.6$ $\mathrm{mm} ; 5 \mu \mathrm{m}$ ), Waters 2998 PDA (Photodiode Array) detector and interfaced to mass detector (Waters TQ (Tandem Quadrupole, WAT-176001263)). Column temperature was maintained at $25{ }^{\circ} \mathrm{C}$ and mobile phase flow rate at $0.7 \mathrm{~mL} / \mathrm{min}$. Elution program which was used described previously by Gođevac et al. [15]. The mobile phase consisted of deionized water containing 0.2 vol.\% formic acid (solvent A) and acetonitrile (solvent $B$ ), with a gradient from 5 to $16 \%$ for solvent $B$ over the first $20 \mathrm{~min}$, then to $40 \% \mathrm{~B}$ for $8 \mathrm{~min}$, to $70 \% \mathrm{~B}$ for $4 \mathrm{~min}$, to $98 \% \mathrm{~B}$ for $4 \mathrm{~min}$, then held at $98 \%$ B for 9 $\mathrm{min}$, then to $5 \% \mathrm{~B}$ for $1 \mathrm{~min}$ and held at $5 \% \mathrm{~B}$ for $9 \mathrm{~min}$ for reconditioning of the column. Injection volume was $10 \mu \mathrm{L}$. The PDA detector measured absorbance in the range from 190 to $600 \mathrm{~nm}$.

\section{Triple quadrupole-mass spectrometry (TQ-MS)/mass} spectrometry-multiple reaction monitoring (MS-MRM)

Identification of phenolic compounds was conducted by comparison of retention times $\left(t_{R}\right)$, ultra- violet maxima $\left(\lambda_{\max }\right)$ and mass spectra of phenolic compound standards and samples. Quantification was made by the method of external standards, importing the obtained area of recorded samples of fruit wine into calibration curves of standards. Methanolic solutions of phenolic compound standards were made and their concentrations were $0.0001,0.001,0.01,0.1$ and $1 \mathrm{mg} / \mathrm{mL}$, with chromatograms also recorded by injection of $1,2,4,6,8$ and $10 \mu \mathrm{L}$ to each compound. By integrating the areas of obtained peaks, we got the values which were used to make calibration curves for phenolic compound standards. Conditions for quantification of phenolic compounds with Waters Acquity UPLC H-Class device, which involves ionization modes, cone voltages, collision energies and MRM (multiple reaction monitoring) transitions, were obtained by direct injection of methanolic solutions of phenolic standards into the mass spectrometer using the IntelliStart program (Waters, Milford, MA, USA; 2005) shown in Table 1. Capillary voltage of $3.5 \mathrm{kV}$, extractor voltage of $3 \mathrm{~V}$, source temperature of $150{ }^{\circ} \mathrm{C}$, desolvation temperature of $450{ }^{\circ} \mathrm{C}$ and desolvation gas flow of 900 $\mathrm{L} / \mathrm{h}$ were the conditions under which electrospray ionization (ESI) ion source operated. The spectra were recorded both in positive and negative modes where we got $[\mathrm{M}+\mathrm{H}]^{+}$and $[\mathrm{M}-\mathrm{H}]^{-}$, respectively, as parent ions, and during the collision with argon as a collision gas, we got product ions. MassLynx V4.1 software (Waters, Milford, MA, USA; 2005) was used for data acquisition and processing. Representative HPLC MRM chromategrams of wine from black chokeberry with sugar added are presented on Fig. 1.

Table 1. The parameters for identification and quantification of phenolic compounds in fruit wines; ESI - electrospray ionization, $M R M-$ multiple reaction monitoring, $t_{R}-$ retention time, $\lambda_{\max }-u$ ltraviolet maximum

\begin{tabular}{lcccccccc}
\hline Phenolic compound & $\begin{array}{c}\text { Molecular } \\
\text { formula }\end{array}$ & Mass & $\begin{array}{c}\text { Ionization } \\
\text { modeESI }\end{array}$ & $\begin{array}{c}\text { MRM } \\
\text { transition }\end{array}$ & $\begin{array}{c}\text { Cone } \\
\text { voltage, } \mathrm{V}\end{array}$ & $\begin{array}{c}\text { Collision } \\
\text { energy, eV }\end{array}$ & $t_{\mathrm{R}} / \mathrm{min}$ & $\lambda_{\text {max }} / \mathrm{nm}$ \\
\hline Epicatechin & $\mathrm{C}_{15} \mathrm{H}_{14} \mathrm{O}_{6}$ & 290 & + & $291 \rightarrow 139$ & 26 & 16 & 20.30 & 233,278 \\
Kaempferol & $\mathrm{C}_{15} \mathrm{H}_{10} \mathrm{O}_{6}$ & 286 & + & $287 \rightarrow 153$ & 56 & 36 & 31.52 & 265,361 \\
Sinapinic acid & $\mathrm{C}_{11} \mathrm{H}_{12} \mathrm{O}_{5}$ & 224 & + & $225 \rightarrow 175$ & 12 & 14 & 25.37 & 240,324 \\
Gallic acid & $\mathrm{C}_{7} \mathrm{H}_{6} \mathrm{O}_{5}$ & 170 & - & $169 \rightarrow 125$ & 30 & 20 & 4.74 & 217,271 \\
Protocatechuic acid & $\mathrm{C}_{7} \mathrm{H}_{6} \mathrm{O}_{4}$ & 154 & - & $153 \rightarrow 109$ & 30 & 20 & 9.18 & 218,260 \\
p-Hydroxybenzoic acid & $\mathrm{C}_{7} \mathrm{H}_{6} \mathrm{O}_{3}$ & 138 & - & $137 \rightarrow 93$ & 30 & 20 & 14.30 & 255 \\
Catechin & $\mathrm{C}_{15} \mathrm{H}_{14} \mathrm{O}_{6}$ & 290 & + & $291 \rightarrow 139$ & 26 & 20 & 15.82 & 233,279 \\
Chlorogenic acid & $\mathrm{C}_{16} \mathrm{H}_{18} \mathrm{O}_{9}$ & 354 & + & $355 \rightarrow 163$ & 20 & 12 & 15.62 & 246,325 \\
Vanillic acid & $\mathrm{C}_{8} \mathrm{H}_{8} \mathrm{O}_{4}$ & 168 & + & $169 \rightarrow 93$ & 26 & 14 & 17.16 & 260,291 \\
Caffeic acid & $\mathrm{C}_{9} \mathrm{H}_{8} \mathrm{O}_{4}$ & 180 & - & $179 \rightarrow 135$ & 30 & 20 & 18.04 & 243,323 \\
p-Coumaric acid & $\mathrm{C}_{9} \mathrm{H}_{8} \mathrm{O}_{3}$ & 164 & + & $165 \rightarrow 91$ & 22 & 22 & 23.86 & 230,309 \\
Rutin & $\mathrm{C}_{27} \mathrm{H}_{30} \mathrm{O}_{16}$ & 610 & - & $609 \rightarrow 301$ & 60 & 20 & 25.08 & 253,341 \\
Ellagic acid & $\mathrm{C}_{14} \mathrm{H}_{6} \mathrm{O}_{8}$ & 302 & + & $303 \rightarrow 89$ & 50 & 56 & 25.51 & 253,360 \\
Naringenin & $\mathrm{C}_{15} \mathrm{H}_{12} \mathrm{O}_{5}$ & 272 & + & $273 \rightarrow 153$ & 24 & 24 & 31.32 & 288 \\
Quercetin & $\mathrm{C}_{15} \mathrm{H}_{10} \mathrm{O}_{7}$ & 302 & - & $301 \rightarrow 151$ & 30 & 20 & 29.93 & 254,375 \\
\hline
\end{tabular}



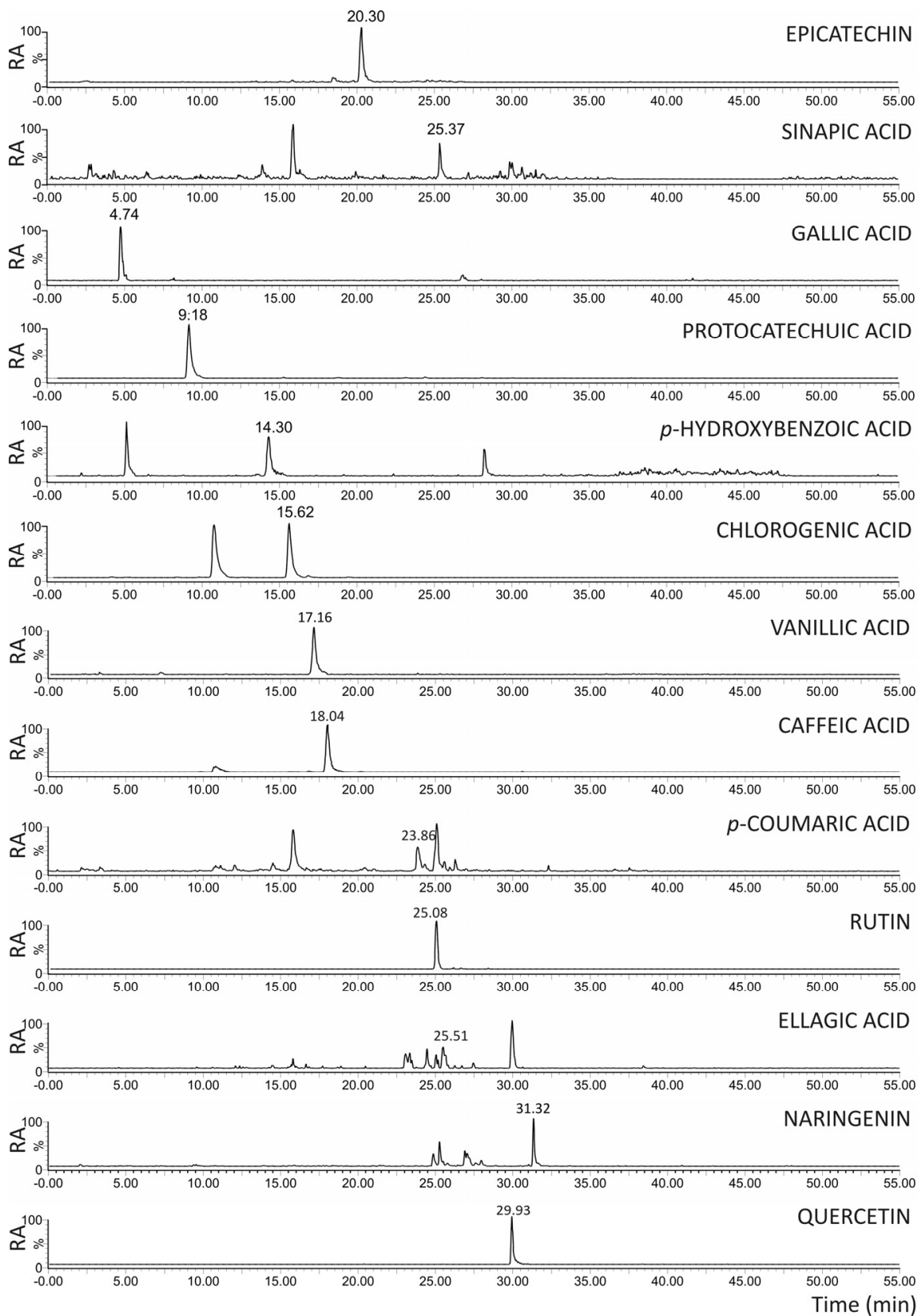

Figure 1. Extracted MRM chromatograms of phenolic compounds of black chokeberry wine with sugar added; RA - relative abundance.

\section{FRAP test and DPPH method}

Ferric reducing activity of plasma (FRAP) is a simple and direct test of measuring antioxidant activity. This method was used for detecting antioxidant activity in fruit wine samples [16]. The results were expressed in $\mathrm{mmol} / \mathrm{L} \mathrm{Fe}^{2+}$. All samples were measured in triplicate.

There is another method available for testing the ability of compounds to act as free radical scavengers or hydrogen donors $[17,18]$. This method involves a stable radical molecule 2,2-diphenyl-1-picrylhydrazyl (DPPH). The results are expressed as mean scavenging concentration, $I C_{50}$ (inhibition concentration), the value representing the amount of antioxidant necessary to decrease DPPH radical concentration by $50 \%$. Prior to testing, wine samples were diluted with water in concentrations from 1:25 to 1:140. Experimental findings have demonstrated that this range allows for linearity between absorbance and concentration. Samples showing weaker antioxidant activity, such as apple wine, were diluted with the ratio from $4: 1$ to $1: 1$ (wine:water). Each sample was prepared in 5 dilutions, in triplicates. $I C_{50}$ value was obtained from the chart where the inhibition percentage is presented against concentration $I \%=f(c)$. Percentage of DPPH radical inhibition was calculated according to equation: 
$\left.I(\%)=100\left(A_{\text {blank }}-A_{\text {sample }}\right) / A_{\text {blank }}\right)$

where $A_{\text {blank }}$ only relates to absorbance reading of DPPH with water, while $A_{\text {sample }}$ stands for absorbance reading of DPPH after reaction with the tested wine sample. The results were expressed as reciprocal value I(\%) multiplied by 100 .

\section{Total phenolic content}

Total phenolic content in fruit wine samples was determined by Folin-Ciocalteu (FC) method using gallic acid as a standard [19]. Before the analysis, fruit wine samples were filtered through the membrane filter $(0.45 \mu \mathrm{m})$, then diluted 20 times with distilled water. After $2 \mathrm{~h}$ of incubation in the dark at room temperature, the absorbance of standards and fruit wine samples was measured at $740 \mathrm{~nm}$ on UV-Vis spectrophotometer Evolution 300, Thermo Scientific (Waltham, MA, USA). All samples were measured in triplicate. The results were expressed in $\mathrm{mg} / \mathrm{L}$ of gallic acid equivalents (mg GAE/L).

\section{Total antioxidant activity corrected by the amount of $\mathrm{SO}_{2}$ present in the wines}

For this purpose, a sequence of dilutions with increasing free $\mathrm{SO}_{2}$ concentration was made (from 10 to $25 \mathrm{mg} / \mathrm{L}$ ). After that, the amount of $0.08 \mathrm{~g}$ of tartaric acid was dissolved in $1 \mathrm{~L}$ of distilled water in order to ensure a $\mathrm{pH}$ value of 3.25 which was the average $\mathrm{pH}$ value for the tested wines. Then, $\mathrm{K}_{2} \mathrm{~S}_{2} \mathrm{O}_{5}$ was added in the amount necessary to provide free $\mathrm{SO}_{2}$ concentration at the interval from 10 to $25 \mathrm{mg} / \mathrm{L}$. Free $\mathrm{SO}_{2}$ concentration was monitored by iodometric titration according to Ripper, both in model solutions and in fruit wine samples [20]. The absorbance of model solutions was read at $593 \mathrm{~nm}$, the same as for FRAP test. Finally, the corrected value of total antioxidant activity of wines - FRAP corr. was calculated as the difference between the values of wine samples with contained free $\mathrm{SO}_{2}$ concentration $\left(F R A P_{\text {total }}\right)$ and values of model solutions with the same $\mathrm{SO}_{2}$ concentration (FRAP $\left.P_{\text {model solution }}\right)$ obtained from Fig. 2.

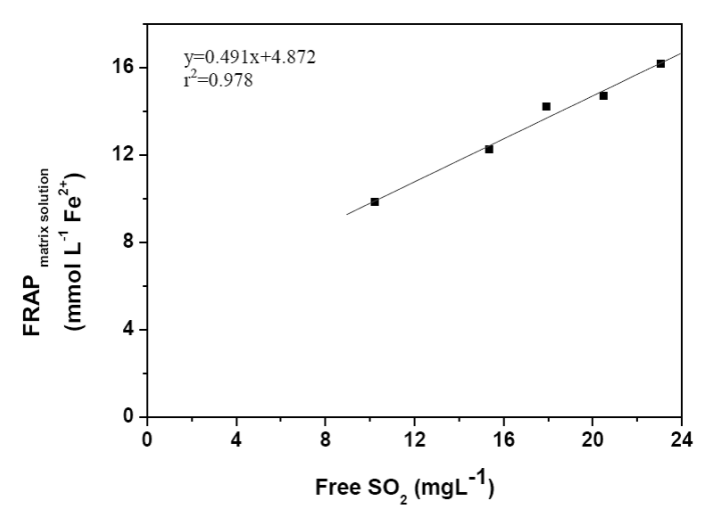

Figure 2. Correlation between free $\mathrm{SO}_{2}$ and $F R A P_{\text {model solution. }}$

\section{Statistical analysis}

The statistical analysis was performed using the software SPSS Statistic V22.0 (IBM, Chicago, IL, USA; 2014) for paired samples test and one-way ANOVA with Tukey post hoc test. Linear regression correlation analysis in Origin Pro 8 (OriginLab, Northampton, MA, USA; 2008) was used to test associations between variables.

\section{RESULTS AND DISCUSSION}

\section{Results of physicochemical characterization of wine samples}

Table 2 presents the obtained results for total soluble solids ( $\left.{ }^{\circ} \mathrm{Brix}\right), \mathrm{pH}$ value, total titratable acidity and alcohol (vol.\%) in the analysed samples.

Table 2. Physicochemical characterization of wine samples; values are mean \pm standard deviations( $n=3$ )

\begin{tabular}{|c|c|c|c|c|}
\hline $\begin{array}{l}\text { Wine sample } \\
\text { Fruit/sugar }\end{array}$ & $\begin{array}{c}\text { Total soluble solids } \\
\text { must, }{ }^{\circ} \text { Brix }\end{array}$ & $\mathrm{pH}$ & $\begin{array}{c}\text { Total titratable acid } \\
\text { malic acid g/L }\end{array}$ & $\begin{array}{c}\text { Alcohol content } \\
\text { vol. } \%\end{array}$ \\
\hline Raspberry w/o sugar & $14.3 \pm 0.3$ & $3.16 \pm 0.01$ & $13.46 \pm 0.12$ & $7.91 \pm 0.06$ \\
\hline Raspberry with sugar & $16.5 \pm 0.3$ & $2.85 \pm 0.01$ & $13.80 \pm 0.11$ & $9.43 \pm 0.07$ \\
\hline Blackberry w/o sugar & $13.9 \pm 0.4$ & $2.87 \pm 0.01$ & $8.28 \pm 0.09$ & $7.63 \pm 0.08$ \\
\hline Blackberry with sugar & $18.5 \pm 0.2$ & $2.94 \pm 0.02$ & $7.45 \pm 0.09$ & $10.47 \pm 0.06$ \\
\hline Blueberry w/o sugar & $14.3 \pm 0.4$ & $2.86 \pm 0.02$ & $6.76 \pm 0.08$ & $7.88 \pm 0.09$ \\
\hline Blueberry with sugar & $19.0 \pm 0.3$ & $2.85 \pm 0.01$ & $7.94 \pm 0.11$ & $10.82 \pm 0.08$ \\
\hline Black chokeberry w/o sugar & $10,1 \pm 0.3$ & $3.66 \pm 0.02$ & $9.32 \pm 0.09$ & $5.51 \pm 0.09$ \\
\hline Black chokeberry with sugar & $11.5 \pm 0.3$ & $3.53 \pm 0.01$ & $10.35 \pm 0.07$ & $6.19 \pm 0.08$ \\
\hline Apple w/o sugar & $13.5 \pm 0.3$ & $3.38 \pm 0.02$ & $4.97 \pm 0.08$ & $7.36 \pm 0.05$ \\
\hline Apple with sugar & $16.0 \pm 0.3$ & $3.79 \pm 0.02$ & $4.14 \pm 0.06$ & $9.17 \pm 0.09$ \\
\hline Sour cherry w/o pit with sugar & $19.4 \pm 0.2$ & $3.34 \pm 0.02$ & $8.14 \pm 0.09$ & $10.93 \pm 0.09$ \\
\hline Sour cherry with pit with sugar & $19.8 \pm 0.2$ & $3.44 \pm 0.01$ & $7.94 \pm 0.07$ & $11.31 \pm 0.06$ \\
\hline Sour cherry w/o pit w/o sugar & $12.6 \pm 0.4$ & $3.43 \pm 0.01$ & $6.90 \pm 0.08$ & $6.85 \pm 0.09$ \\
\hline Sour cherry with pit w/o sugar & $13.3 \pm 0.3$ & $3.45 \pm 0.01$ & $6.90 \pm 0.09$ & $7.23 \pm 0.07$ \\
\hline
\end{tabular}




\section{Results of HPLC-TQ-MS/MS analysis}

Antioxidant properties of many compounds found in plant material are proportional to the content of phenolic compounds. Antioxidants are substances present in low concentrations compared to biomolecules prone to oxidation such as DNA, proteins, lipids and carbohydrates. Their main role is to prevent free radical-induced damage of the cells [21].

Phytochemicals are responsible for the antioxidant capacity of fruit wines and they include phenolic acids, anthocyanins and other flavonoid compounds [22].

Table 3 illustrates the phenolic content in the test samples. The results obtained from HPLC-TQ-MS/MS which were statistically analysed using parametric test are shown in Table 4. Statistical significance was confirmed with $95 \%$ confidence interval for all wine samples $(p<0.05)$ except for apple wine with and without added sugar $(p=0.073)$. Variables which were used in paired samples test were the results from Table 3 for wines with and without added sugar. Content of phenolic compounds presented in Table 3 depends on the sugar content in the analysed samples. Increased amount of sugar resulted in increased alcohol concentration in the produced fruit wine. As an extracting agent, alcohol contributes to higher phenolic content. The distribution of anthocyanins and polyphenolics is not uniform in fruit tissue. High content of anthocyanins and polyphenols is especially present in the skin [23]. This is because they act as photoprotective agents and attractants for seed dispersal [1].

Procyanidins and anthocyanins are polyphenol subgroups which are present in high amounts in sour cherries and red berries. A noticeable content of colourless and pale yellow polyphenols was also observed, with marked biological activity [24].

In the analysed samples, some compounds were present in all fruit wines while some were only present in certain fruit wines.

Table 3. Content of selected polyphenols in analyzed samples ( $\mu \mathrm{g} / \mathrm{mL}) ; 1$ - apple w/o sugar; 2 - apple with sugar; 3 - blueberry w/o sugar; 4 -blueberry with sugar; 5 - black chokeberry w/o sugar; 6-black chokeberry with sugar; 7-blackberry w/o sugar;

8 - blackberry with sugar; 9 - sour cherry w/o sugar, w/o pit; 10 - sour cherry, with sugar, w/o pit; 11 - sour cherry, w/o sugar, with pit; 12 - sour cherry, with sugar, with pit; 13 - raspberry w/o sugar; 14 -raspberry with sugar; $n . d$. - not detected, values are mean \pm standard deviation $(n=3)$

\begin{tabular}{|c|c|c|c|c|c|c|c|c|c|c|c|c|c|c|}
\hline Phenolic compounds & 1 & 2 & 3 & 4 & 5 & 6 & 7 & 8 & 9 & 10 & 11 & 12 & 13 & 14 \\
\hline Epicatechin & $\begin{array}{c}22.84 \pm \\
0.38\end{array}$ & $\begin{array}{l}39.47 \\
\pm 0.35\end{array}$ & $\begin{array}{l}27.84 \\
\pm 0.31\end{array}$ & $\begin{array}{l}42.69 \\
\pm 0.26\end{array}$ & $\begin{array}{c}5.94 \\
\pm 0.22\end{array}$ & $\begin{array}{c}7.17 \\
\pm 0.25\end{array}$ & $\begin{array}{l}35.75 \\
\pm 0.78\end{array}$ & $\begin{array}{l}52.68 \\
\pm 0.57\end{array}$ & $\begin{array}{c}111.68 \\
\pm 1.11\end{array}$ & $\begin{array}{c}134.42 \\
\pm 1.07\end{array}$ & $\begin{array}{c}114.69 \\
\pm 1.26\end{array}$ & $\begin{array}{c}126.44 \\
\pm 1.26\end{array}$ & $\begin{array}{l}55.51 \\
\pm 1.16\end{array}$ & $\begin{array}{r}75.91 \\
\pm 1.89\end{array}$ \\
\hline Kaempferol & n.d. & n.d. & n.d. & n.d. & n.d. & n.d. & n.d. & n.d. & $\begin{array}{c}2.09 \\
\pm 0,08\end{array}$ & $\begin{array}{c}5.00 \\
\pm 0.14\end{array}$ & n.d. & n.d. & n.d. & n.d. \\
\hline Sinapinic acid & n.d. & n.d. & $\begin{array}{c}0.60 \\
\pm 0.03\end{array}$ & $\begin{array}{c}1.63 \\
\pm 0.07\end{array}$ & $\begin{array}{c}0.16 \\
\pm 0.01\end{array}$ & $\begin{array}{c}0.37 \\
\pm 0.01\end{array}$ & $\begin{array}{c}2.19 \\
\pm 0.10\end{array}$ & $\begin{array}{c}2.85 \\
\pm 0.08\end{array}$ & $\begin{array}{c}2.36 \\
\pm 0.08\end{array}$ & $\begin{array}{c}3.98 \\
\pm 0.09\end{array}$ & $\begin{array}{c}2.17 \\
\pm 0.10\end{array}$ & $\begin{array}{c}3.14 \\
\pm 0.11\end{array}$ & $\begin{array}{c}2.65 \\
\pm 0.11\end{array}$ & $\begin{array}{c}2.82 \\
\pm 0.11\end{array}$ \\
\hline Gallic acid & n.d. & n.d. & $\begin{array}{l}19.86 \\
\pm 0.34\end{array}$ & $\begin{array}{l}32.05 \\
\pm 0.80\end{array}$ & $\begin{array}{c}1.82 \\
\pm 0.03\end{array}$ & $\begin{array}{c}2.55 \\
\pm 0.04\end{array}$ & $\begin{array}{l}92.15 \\
\pm 1.29\end{array}$ & $\begin{array}{c}100.17 \\
\pm 1.20\end{array}$ & n.d. & n.d. & n.d. & n.d. & $\begin{array}{l}38.28 \\
\pm 0.73\end{array}$ & $\begin{array}{l}55.74 \\
\pm 1.11\end{array}$ \\
\hline Protocatechuic acid & n.d. & n.d. & $\begin{array}{l}29.75 \\
\pm 0.38\end{array}$ & $\begin{array}{l}42.25 \\
\pm 0.97\end{array}$ & $\begin{array}{l}42.53 \\
\pm 0.72\end{array}$ & $\begin{array}{l}49.11 \\
\pm 0.44\end{array}$ & $\begin{array}{l}17.36 \\
\pm 0.60\end{array}$ & $\begin{array}{l}25.18 \\
\pm 0.78\end{array}$ & $\begin{array}{l}17.62 \\
\pm 0.56\end{array}$ & $\begin{array}{l}28.44 \\
\pm 0.39\end{array}$ & $\begin{array}{l}15.10 \\
\pm 0.30\end{array}$ & $\begin{array}{l}17.84 \\
\pm 0.53\end{array}$ & n.d. & n.d. \\
\hline p- Hydroxybenzoic acid & $\begin{array}{c}0.95 \\
\pm 0.03\end{array}$ & $\begin{array}{c}3.76 \\
\pm 0.09\end{array}$ & $\begin{array}{c}1.39 \\
\pm 0.06\end{array}$ & $\begin{array}{c}4.83 \\
\pm 0.22\end{array}$ & $\begin{array}{c}4.20 \\
\pm 0.19\end{array}$ & $\begin{array}{c}6.53 \\
\pm 0.29\end{array}$ & $\begin{array}{c}3.70 \\
\pm 0.18\end{array}$ & $\begin{array}{c}4.18 \\
\pm 0.20\end{array}$ & $\begin{array}{l}13.56 \\
\pm 0.51\end{array}$ & & & & $\begin{array}{l}37.13 \\
\pm 0.92\end{array}$ & $\begin{array}{l}49.89 \\
\pm 0.99\end{array}$ \\
\hline Catechin & $\begin{array}{c}1.28 \\
\pm 0.06\end{array}$ & $\begin{array}{c}3.65 \\
\pm 0.14\end{array}$ & $\begin{array}{c}1.71 \\
\pm 0.07\end{array}$ & $\begin{array}{c}4.52 \\
\pm 0.22\end{array}$ & n.d. & n.d. & $\begin{array}{c}1.85 \\
\pm 0.09\end{array}$ & $\begin{array}{c}2.16 \\
\pm 0,10\end{array}$ & $\begin{array}{l}23.62 \\
\pm 0.71\end{array}$ & $\begin{array}{l}29.73 \\
\pm 0.80\end{array}$ & $\begin{array}{l}22.32 \\
\pm 0.71\end{array}$ & $\begin{array}{l}25.67 \\
\pm 0.90\end{array}$ & $\begin{array}{c}3.43 \\
\pm 0.16\end{array}$ & $\begin{array}{c}4.01 \\
\pm 0.18\end{array}$ \\
\hline Chlorogenic acid & $\begin{array}{l}70.71 \\
\pm 0.78\end{array}$ & $\begin{array}{l}92.38 \\
\pm 0.92\end{array}$ & $\begin{array}{c}390.75 \\
\pm 1.95\end{array}$ & $\begin{array}{c}474.34 \\
\pm 3.32\end{array}$ & $\begin{array}{c}390.75 \\
\pm 2.74\end{array}$ & $\begin{array}{c}400.05 \\
\pm 3.20\end{array}$ & n.d. & n.d. & $\begin{array}{c}345.74 \\
\pm 3.46\end{array}$ & $\begin{array}{c}370.03 \\
\pm 1.85\end{array}$ & $\begin{array}{c}340.46 \\
\pm 2.72\end{array}$ & $\begin{array}{c}350.09 \\
\pm 2.10\end{array}$ & n.d. & n.d. \\
\hline Vanillic acid & $\begin{array}{c}1.16 \\
\pm 0.05\end{array}$ & $\begin{array}{c}4.22 \\
\pm 0.13\end{array}$ & $\begin{array}{c}4.69 \\
\pm 0.18\end{array}$ & $\begin{array}{c}8.11 \\
\pm 0.25\end{array}$ & $\begin{array}{c}5.31 \\
\pm 0.16\end{array}$ & $\begin{array}{c}5.85 \\
\pm 0.18\end{array}$ & $\begin{array}{c}5.14 \\
\pm 0.17\end{array}$ & $\begin{array}{c}5.55 \\
\pm 0.18\end{array}$ & $\begin{array}{c}9.80 \\
\pm 0.24\end{array}$ & $\begin{array}{l}14.65 \\
\pm 0.30\end{array}$ & $\begin{array}{c}8.78 \\
\pm 0.26\end{array}$ & $\begin{array}{l}12.91 \\
\pm 0.24\end{array}$ & $\begin{array}{c}1.06 \\
\pm 0.053\end{array}$ & $\begin{array}{r}1.58 \\
\pm 0.077\end{array}$ \\
\hline Caffeic acid & $\begin{array}{c}0.5 \\
\pm 0.01\end{array}$ & $\begin{array}{c}2.8 \\
\pm 0.05\end{array}$ & $\begin{array}{l}39.44 \\
\pm 0.32\end{array}$ & $\begin{array}{c}55.30 \\
\pm 0.5\end{array}$ & $\begin{array}{l}25.37 \\
\pm 1.01\end{array}$ & $\begin{array}{l}35.30 \\
\pm 0.55\end{array}$ & $\begin{array}{c}2.44 \\
\pm 0.11\end{array}$ & $\begin{array}{c}3.78 \\
\pm 0.08\end{array}$ & $\begin{array}{c}2.22 \\
\pm 0.08\end{array}$ & $\begin{array}{c}4.49 \\
\pm 0.14\end{array}$ & $\begin{array}{c}1.89 \\
\pm 0.08\end{array}$ & $\begin{array}{c}2.25 \\
\pm 0.09\end{array}$ & $\begin{array}{c}1.78 \\
\pm 0.09\end{array}$ & $\begin{array}{c}2.26 \\
\pm 0.10\end{array}$ \\
\hline$p$-Coumaric acid & n.d. & n.d. & $\begin{array}{c}9.75 \\
\pm 0.21\end{array}$ & $\begin{array}{l}18.43 \\
\pm 0.37\end{array}$ & $\begin{array}{c}1.49 \\
\pm 0.082\end{array}$ & $\begin{array}{c}1.53 \\
\pm 0.076\end{array}$ & n.d. & n.d. & n.d. & n.d. & $\begin{array}{c}1.10 \\
\pm 0.04\end{array}$ & $\begin{array}{c}2.11 \\
\pm 0.10\end{array}$ & n.d. & $\begin{array}{c}3.08 \\
\pm 0.13\end{array}$ \\
\hline Rutin & n.d. & n.d. & n.d. & n.d. & $\begin{array}{l}31.05 \\
\pm 0.47\end{array}$ & $\begin{array}{l}36.34 \\
\pm 0.72\end{array}$ & n.d. & n.d. & n.d. & n.d. & n.d. & n.d. & n.d. & n.d. \\
\hline Ellagic acid & n.d. & n.d. & $\begin{array}{c}9.49 \\
\pm 0.11\end{array}$ & $\begin{array}{l}17.53 \\
\pm 0.61\end{array}$ & $\begin{array}{c}8.00 \\
\pm 0.17\end{array}$ & $\begin{array}{l}10.09 \\
\pm 0.20\end{array}$ & $\begin{array}{r}132.97 \\
\pm 1.06\end{array}$ & $\begin{array}{c}140.20 \\
\pm 1.68\end{array}$ & n.d. & n.d. & n.d. & n.d. & $\begin{array}{l}21.82 \\
\pm 0.65\end{array}$ & $\begin{array}{l}33.75 \\
\pm 1.00\end{array}$ \\
\hline Naringenin & $\begin{array}{c}0.12 \\
\pm 0.004\end{array}$ & $\begin{array}{c}0.81 \\
\pm 0.03\end{array}$ & $\begin{array}{c}0.21 \\
\pm 0.01\end{array}$ & $\begin{array}{c}1.53 \\
\pm 0.06\end{array}$ & $\begin{array}{c}0.16 \\
\pm 0.008\end{array}$ & $\begin{array}{c}0.24 \\
\pm 0.011\end{array}$ & $\begin{array}{c}0.42 \\
\pm 0.02\end{array}$ & $\begin{array}{c}0.49 \\
\pm 0.02\end{array}$ & $\begin{array}{c}2.78 \\
\pm 0.11\end{array}$ & $\begin{array}{c}4.04 \\
\pm 0.12\end{array}$ & $\begin{array}{r}2.30 \\
\pm 0.09\end{array}$ & $\begin{array}{c}3.38 \\
\pm 0.12\end{array}$ & $\begin{array}{c}0.80 \\
\pm 0.04\end{array}$ & $\begin{array}{r}0,96 \\
\pm 0.05\end{array}$ \\
\hline Quercetin & n.d. & n.d. & $\begin{array}{c}6.91 \\
\pm 0.20\end{array}$ & $\begin{array}{l}15.71 \\
\pm 0.33\end{array}$ & $\begin{array}{l}48.00 \\
\pm 0.57\end{array}$ & $\begin{array}{l}58.21 \\
\pm 0.64\end{array}$ & $\begin{array}{c}9.63 \\
\pm 0.33\end{array}$ & $\begin{array}{l}10.50 \\
\pm 0.31\end{array}$ & $\begin{array}{l}40.32 \\
\pm 0.80\end{array}$ & $\begin{array}{l}50.75 \\
\pm 0.76\end{array}$ & $\begin{array}{l}39.51 \\
\pm 0.98\end{array}$ & $\begin{array}{l}48.92 \\
\pm 0.88\end{array}$ & $\begin{array}{c}8.89 \\
\pm 0.35\end{array}$ & $\begin{array}{l}12.63 \\
\pm 0.50\end{array}$ \\
\hline
\end{tabular}


Table 4. Paired samples test results; 1 -apple w/o sugar; 2 -apple with sugar; 3 -blueberry w/o sugar; 4 -blueberry with sugar; 5 - black chokeberry w/o sugar; 6 - black chokeberry with sugar; 7 - blackberry w/o sugar; 8 - blackberry with sugar; 9 - sour cherry w/o sugar, w/o pit; 10 - sour cherry, with sugar, w/o pit; 11 - sour cherry, w/o sugar, with pit; 12 - sour cherry, with sugar, with pit; 13 - raspberry w/o sugar; 14 - raspberry with sugar

\begin{tabular}{lccccccc}
\hline Parameter & 1,2 & 3,4 & 5,6 & 7,8 & 9,10 & 11,12 \\
\hline $\mathrm{t}$ & 1.935 & 2.213 & 2.512 & 2.320 & 3.056 & 2.974 & 2.581 \\
Sig. (2-tailed) & 0.073 & 0.044 & 0.025 & 0.036 & 0.009 & 0.010 & 0.022 \\
\hline
\end{tabular}

The distribution of caffeic acid, chlorogenic acid, $p$-coumaric acid and vanillic acid is widespread in berry crops. Those compounds act as natural antioxidants. The structure and content of individual phenolics in berries influence total antioxidant capacity. One of the abovementioned phenolic acids, chlorogenic acid was detected in significant amounts in blueberries by authors Zheng and Wang [25]. The samples of blueberry wine are a rich source of chlorogenic acid which is in line with the literature [26]. Looking at the content of chlorogenic acid in the analysed samples, it was observed that it was present in higher amounts than all other compounds, until it was found in blackberry and raspberry wine. Presence of chlorogenic acid in apple wine samples produced from the Jonagold variety was confirmed by the analysis of the variety with the same name. [27]. Besides chlorogenic acid, blueberry wine stands out with the highest content of $p$-coumaric acid which was confirmed to be present in this fruit by Hakkinen et al. [28]. Similarly to some other authors Macheix et al. [29], caffeic acid was detected in our fruit wine samples. In comparison with other samples, caffeic acid was present in the largest amounts in blueberry and chokeberry wine. Finnish scientists have shown that caffeic acid is also present in chokeberry and blueberry fruit [28]. The results of one study suggest that the content of caffeic acid depends on a sunexposure-dependent induction of caftaric acid hydrolysis [30]. Protocatechuic acid was present in the largest amounts in blueberry and chokeberry wine until it was found in apple and raspberry wine. Epicatechin and catechin were present in blueberry wine which is in line with their established presence in the fruit [31]. Rutin was found only in chokeberry wine. The analysed samples of cherry wine are a source of caffeic acid, chlorogenic acid and protocatechuic acid. The flavonoid naringenin was also found in the samples. Its content is shown in Table 3 and it is in line with the literature [32]. Epicatechin and vanillic acid were present in the largest amounts in cherry wine, where catechin was also found. The presence of these compounds in the examined wine was also confirmed by cherry analysis carried out by Spanish authors [31]. Catechin and epicatechin were also determined in blackberry, raspberry and apple wine, their presence in corresponding fruits was also confirmed by authors [33]. Blackberry and raspberry wine, according to the data from Table 3, are a rich source of ellagic acid which provides long-term health benefits [34]. The content of ellagic acid in blackberry wine with and w/o sugar was predominant in comparison with other analysed samples, which was confirmed by other authors as well [35]. Literature data shows that ellagic acid was also found in raspberries [28]. Ellagic acid was not found in apple or cherry wine. Fruit phenolic acids such as caffeic acid, $p$-coumaric acid and chlorogenic acid showed activity in inhibiting human LDL oxidation in vitro [36]. Analysis of fruit wine samples showed that they were also a source of flavonols such as quercetin and kaempferol. The largest amounts of quercetin were found in chokeberry wine. The obtained results correspond to tests conducted by Finnish authors which showed that chokeberry had the largest content of quercetin, followed by the blueberry, while the lowest amount was found in the raspberry [37]. Quercetin found in raspberry wine is one of the main flavonols in this fruit, which is in line with literature data [28]. One of the most predominant flavonols in cherry wine was quercetin which was confirmed to be present in cherry fruit as well [38]. Some flavonoids, including quercetin, have beneficial effects on human health, probably through inhibiting the oxidative modification of LDL by macrophages in vitro. The abovementioned compounds inhibit the formation of hydroperoxides and protect $\alpha$-tocopherol present in lipoproteins from oxidation [39]. The cytotoxicity of oxidised LDL in vitro is inhibited by quercetin [40]. Minor amounts of kaempferol were only found in wine made from cherries without pits. The obtained kaempferol results are in conformity with literature data which show that it has not been found in chokeberry, blueberry or raspberry [37]. Flavonoids are natural constituents of food. Their positive effect has been demonstrated in the next study. A Dutch study [41] showed that relative risks of mortality from coronary heart diseases and first myocardial infractions in the group of study participants with the highest flavonoid intake was lower by $50 \%$ than in the group with the lowest flavonoid intake. This data suggests that dietary intake of flavonoids is very important. Red wine is a very rich source of flavonoids and it contains $10-20 \mathrm{mg} / \mathrm{L}$ [42]. It has also been observed that flavonoids reduce thrombosis by inhibiting cyclooxygenases [43]. In the conducted study, high antioxidant activity on LDL oxidation was also detected in catechin, quercetin, cyanidin and caffeic 
acid. Unfortunately, ellagic acid did not show any effects during the experiment [44]. In the same study, caffeic acid proved to be a stronger anti-oxidant in inhibiting LDL oxidation, in comparison to ellagic acid which had more free hydroxyl groups in its structure. The reason for this is the fact that antioxidant activity of flavonoids and phenolic acids may depend on the structural characteristics conferring differences in protein binding [45].

\section{FRAP and DPPH test results}

FRAP test results shown in Table 5 confirm that blackberry wine with added sugar has the highest antioxidant value $\left(F R A P_{\text {corr }}=103.90\right)$ while the lowest value was observed in raspberry wine with added sugar $\left(F R A P_{\text {corr }}=18.04\right)$. Furthermore, it was demonstrated by DPPH test that blackberry wine with added sugar had the highest antioxidant activity $\left(I C_{50}=1.20 \%\right)$ while the lowest activity was measured in apple wine without sugar $\left(I C_{50}=83.33 \%\right)$. Lower $I C_{50}$ value indicates a greater antioxidant activity. DPPH scavenging activity of the analysed wine samples was attributed to the cumulative contribution of different compounds which possess bioactive antioxidant properties.

FRAP and DPPH test results clearly demonstrate that berry fruits have a high level of phenolic content and therefore stronger antioxidant activity. Table 5 shows that berry fruits with deep violet, dark blue and black colour (blueberry, black chokeberry and blackberry) have stronger antioxidant capacity compared to raspberries and apples. With increased alcohol content, the greater concentration of phenolic compounds is extracted and stronger antioxidant power of the obtained product is achieved, as represented in Fig. $3 a$.
This is supported by the fact that values received from FRAP test are higher in the fruit wine samples where sugar was added to the fragmented fruit. The results of FRAP test (Table 5) show that wines made from fruits such as blackberry, blueberry, black chokeberry and cherry had a greater total antioxidant capacity than wines made from other fruits. After performed oneway ANOVA statistical analysis in wine samples without sugar added statistical significant difference was showed for FRAP values between all samples $(p<0.05)$ except for blueberry and black chokeberry as well as for cherry without and cherry with pit $(p>0.05)$. In wine samples with sugar added statistical significant difference was showed between all samples $(p<0.05)$ except for blueberry and black chokeberry as well as for apple and cherry with pit $(p>0.05)$. In connection with our results, Pellegrini et al. [46] showed that among 30 different fruits tested, the highest FRAP value was in the blackberry, while other high values were also present in the cherry and blueberry. Fruit origin and wine-making method extensively affect the content and composition of phenolic compounds present in the wine [47]. Phenolic content in the test samples is significant since phenolic compounds are important secondary metabolites exhibiting not only antioxidant activity, but anti-allergic, anti-inflammatory, antithrombotic, antimutagenic and antitumor properties as well. Moreover, cardioprotective and vasodilatation effects should not be neglected. Phenolic compounds also have considerable antimicrobial effects on a wide range of human pathogens [48]. There is clear clinical and epidemiological evidence proving that phenolic compounds are capable of reducing the risk of chronic non-infectious diseases in humans [49].

Table 5. FRAP and DPPH test results; values are mean \pm standard deviation $(n=3)$

\begin{tabular}{lcccccc}
\hline Wine sample & $\begin{array}{c}\text { FRAP } \\
\text { total } \\
\text { Fruit/sugar }\end{array}$ & $\begin{array}{c}\text { FRAP model solution } \\
\mathrm{mmol} / \mathrm{L} \mathrm{Fe}{ }^{2+}\end{array}$ & $\begin{array}{c}\text { FRAP } \\
\text { corrected } \\
\mathrm{mmol} / \mathrm{L} \mathrm{Fe}{ }^{2+}\end{array}$ & $\begin{array}{c}\mathrm{SO}_{2} \text { share } \\
\%\end{array}$ & $\begin{array}{c}\text { DPPH } / C_{50} \\
\%\end{array}$ & $\begin{array}{c}\text { Total phenolic } \\
\text { content } \\
\mathrm{mg} \mathrm{GAE} / \mathrm{L}\end{array}$ \\
\hline Raspberry w/o sugar & $33.32 \pm 0.29$ & 14.93 & $18.30 \pm 0.29$ & 44.92 & $5.52 \pm 0.09$ & $1418.17 \pm 2.90$ \\
Raspberry with sugar & $35.48 \pm 0.32$ & 17.44 & $18.04 \pm 0.32$ & 49.16 & $5.00 \pm 0.08$ & $1458.87 \pm 2.63$ \\
Blackberry w/o sugar & $104.38 \pm 3.02$ & 9.90 & $94.48 \pm 3.02$ & 9.48 & $1.32 \pm 0.03$ & $2230.46 \pm 1.55$ \\
Blackberry with sugar & $115.06 \pm 4.02$ & 11.16 & $103.90 \pm 4.02$ & 9.69 & $1.20 \pm 0.02$ & $2326.81 \pm 1.27$ \\
Blueberry w/o sugar & $80.34 \pm 1.68$ & 9.90 & $70.44 \pm 1.68$ & 12.32 & $1.49 \pm 0.03$ & $2234.46 \pm 1.51$ \\
Blueberry with sugar & $93.94 \pm 2.62$ & 11.16 & $82.78 \pm 2.62$ & 11.87 & $1.56 \pm 0.05$ & $2289.43 \pm 1.39$ \\
Black chokeberry w/o sugar & $85.56 \pm 2.19$ & 11.16 & $74.40 \pm 2.19$ & 13.03 & $1.56 \pm 0.05$ & $2330.96 \pm 1.25$ \\
Black chokeberry with sugar & $94.55 \pm 2.60$ & 12.41 & $82.14 \pm 2.60$ & 13.12 & $1.26 \pm 0.02$ & $2414.61 \pm 0.98$ \\
Apple w/o sugar & $53.18 \pm 0.65$ & 11.16 & $42.02 \pm 0.65$ & 20.97 & $83.33 \pm 2.80$ & $584.28 \pm 4.98$ \\
Apple with sugar & $65.58 \pm 0.82$ & 12.41 & $53.17 \pm 0.82$ & 18.92 & $54.05 \pm 1.70$ & $770.89 \pm 3.58$ \\
Sour cherry w/o pit with sugar & $71.64 \pm 1.13$ & 13.47 & $58.17 \pm 1.13$ & 18.80 & $1.72 \pm 0.04$ & $2084.28 \pm 1.76$ \\
Sour cherry with pit with sugar & $68.20 \pm 0.92$ & 12.41 & $55.79 \pm 0.92$ & 18.20 & $1.66 \pm 0.06$ & $2180.63 \pm 1.65$ \\
Sour cherry w/o pit w/o sugar & $59.99 \pm 0.71$ & 12.41 & $47.58 \pm 0.71$ & 20.69 & $1.92 \pm 0.07$ & $1899.90 \pm 1.88$ \\
Sour cherry with pit w/o sugar & $61.18 \pm 0.74$ & 14.93 & $46.25 \pm 0.74$ & 24.39 & $1.78 \pm 0.05$ & $1980.46 \pm 1.68$ \\
\hline
\end{tabular}




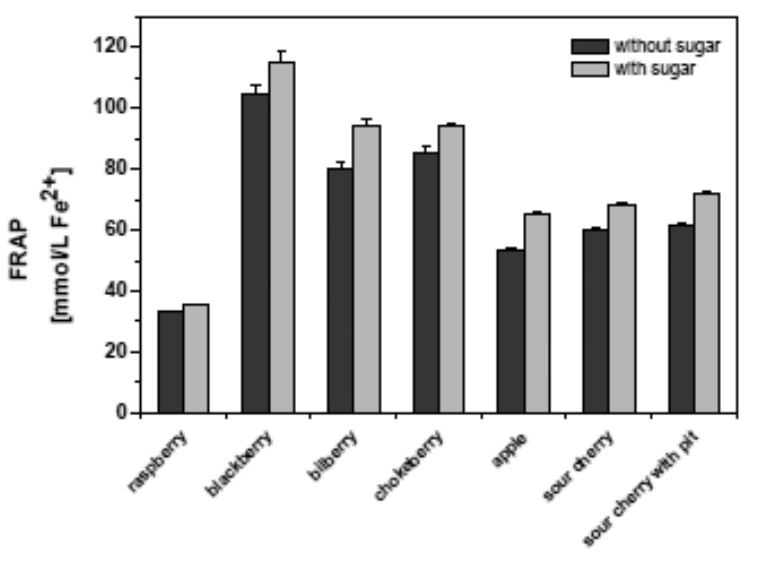

(a)

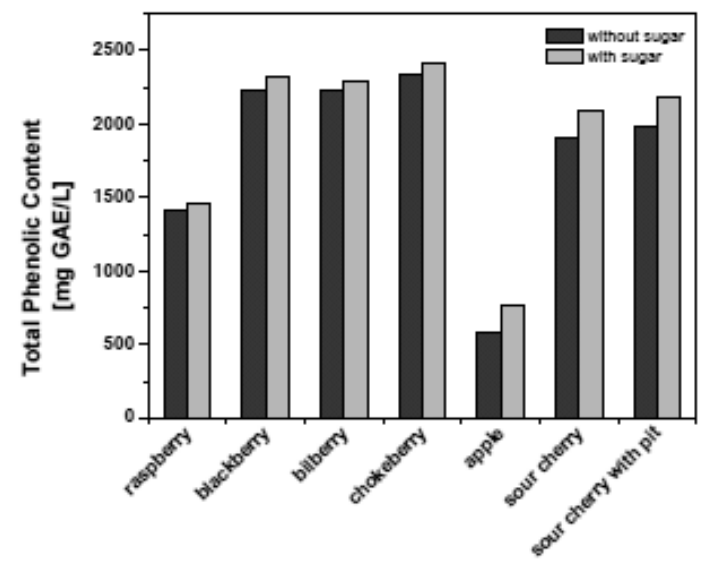

(b)

Figure 3. The comparison of FRAP test (a) and total phenolic content (b) for fruit wines without/with addition of sucrose

\section{Total phenolic content}

Based on the results obtained for the total phenolic content using Folin-Ciocalteau technique, Fig. 3b clearly demonstrates the correlation between the increased amount of sugar, therefore alcohol concentration in wine, and the increased amount of phenol compounds extracted, as expressed in gallic acid equivalents. In wines with higher alcohol content, the polyphenol content increases due to better extraction. [50].

It can be seen from Table 5 that black chokeberry wine with added sugar has the highest total phenolic content when expressed in gallic acid equivalents (2414.61 mg GAE/L), whereas the lowest value was observed in apple wine without added sugar (584.28 mg GAE/L). After performed one-way ANOVA statistical analysis in wine samples without sugar added statistical significant difference was showed for total phenolic content values between all samples $(p<0.05)$ except for blackberry and blueberry $(p>0.05)$. In wine samples with sugar added statistical significant difference was showed between all samples $(p<0.05)$. Authors Zheng and Wang [25] showed that chokeberry fruit had significantly higher total phenolic content than other berries. Among other fruit wine samples, the lowest total phenolic content was also observed in apple wine by authors Vasantha Rupasinghe and Cleggb [47]. Blueberry wine with added sugar has total phenolic content (2289.43 mg GAE/L), while blueberry wine without added sugar has (2234.46 mg GAE/L). Significantly high total phenolic content was proven in the study of blueberry antioxidant capacity [51]. The results for raspberry wine with added sugar were (1458.87 mg GAE/L), while without added sugar (1418.17 mg GAE/L). Results clearly show that total phenolic content is higher in wines made from black chokeberry and blueberry than raspberry. This is to be expected since small berries such as blueberries and black chokeberries, which possess a strong colour and higher proportion of tough skin, have stronger antioxidant activity than those with soft, thin skin and light colour such as raspberries and strawberries [5]. Total phenolic content of cherry wine samples (Table 5) is in agreement with the data found in literature [52].

It can be seen from Fig. 4 that there is a linear correlation between total phenolic content and $F R A P_{\text {corr }}$ value (a) and a linear correlation between total phenolic content and $F R A P_{\text {total }}$ (b). Obviously, wine represents a complex composition of phenolic compounds so

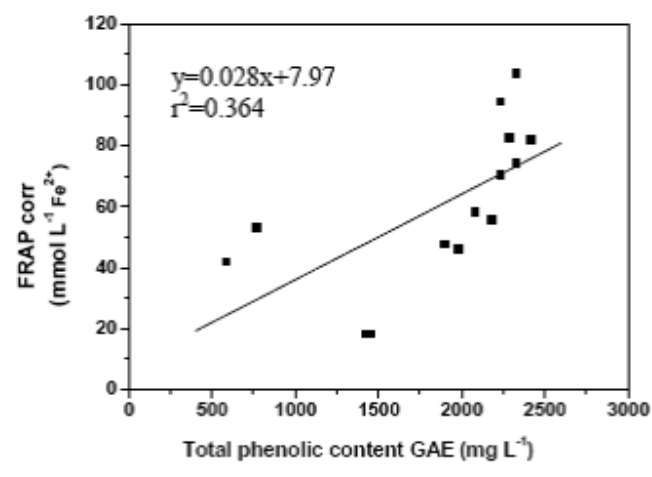

(a)

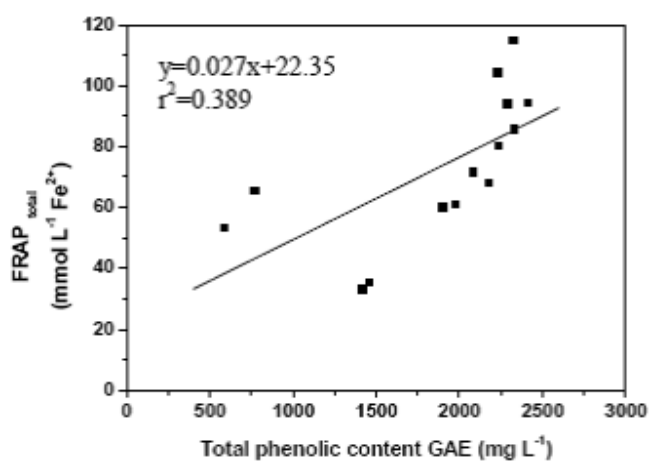

(b)

Figure 4. Linear correlation between: a) total phenolic content and FRAP $P_{\text {corr }}$ and $\left.b\right)$ total phenolic content and FRAP $P_{\text {total. }}$ 
its antioxidant properties cannot be attributed to a particular compound alone but rather, they should be seen as a cumulative effect of many. Wine and plants used as food are a rich source of different phenolic antioxidants which interact to demonstrate synergistic protection against LDL oxidation [53]. However, it is important to distinguish which group of phenolic compounds is the most significant for estimating the antioxidant properties of wine. According to the authors Katalinic et al. [16] who conducted a study on grape wines, phenolic compounds derived from solid parts (seeds, skins, stalks) are extracted in wine during the maceration process, thus influencing antioxidant properties of the end product.

\section{CONCLUSION}

It can be concluded from our results that the analysed wine samples are a source of specific antioxidant phenolic compounds. Alcohol content is also a very important factor for better extraction of antioxidants in fruit wines. Antioxidant content in fruit wines depends on the type of fruit they are made from, cultivation conditions and wine-making techniques.

Regular intake of antioxidants through diet and especially from berry fruits has well documented health benefits. Phenolic content in the analysed samples proved to be significant since they are important secondary metabolites exhibiting not only antioxidant properties, but also other health benefits. Berries are a reservoir of minerals and water, and this is another reason for their particularly important role in nutrition. Phenolic and other compounds present in the wine showed synergistic and antagonistic effects which influenced antioxidant activity of berry or fruit wine. Various fruit wines are a particular source of phenolic compounds which, besides antioxidant properties, possess other important health benefits as well.

\section{Acknowledgements}

Our work was supported by the Scientific Research Project III 46001 of the Ministry of Education, Science and Technological Development of the Republic of Serbia.

\section{REFERENCES}

[1] A. Chaovanalikit, R.E. Wrolstad, Total anthocyanins and total phenolics of fresh and processed cherries and their antioxidant properties, J. Food Sci. 69 (2004) 67-72.

[2] S.Y. Sun, W.G. Jiang, Y.P. Zhao, Comparison of aromatic and phenolic compounds in cherry wines with different cherry cultivars by HS-SPME-GC-MS and HPLC, Int. J. Food Sci. Tech. 47 (2012) 100-106.

[3] R. Flamini, P. Traldi, Mass spectrometry in grape and wine chemistry, John Wiley \& Sons Inc, Hoboken, NJ, 2010, p. 163.
[4] A. Bertelli, Wine, research and cardiovascular disease: Instructions for use. Atherosclerosis. 195 (2007) 242$-247$.

[5] I.M. Heinonen, P.J. Lehtonen, A.I. Hopia, Antioxidant activity of berry and fruit wines and liquors, J. Agr. Food Chem. 46 (1998) 25-31.

[6] B. Negi, G. Dey, Comparative analysis of total phenolic content in sea buckthorn wine and other selected fruit wines, World Acad. Sci. Eng. Tech. 3 (2009) 331-334.

[7] A. Scalbert, C. Manach, C. Morand, C. Remesy, L. Jimenez, Dietary polyphenols and the prevention of diseases, Crit. Rev. Food Sci. 45 (2005) 287-306.

[8] H.D. Belitz, W.Grosch, Food chemistry, Springer Verlag, Berlin,1987, p. 774.

[9] J.Y. Cho, J.H. Jeong, J.Y. Kim, S.R. Kim, S.J. Kim, H.J. Lee, S.H. Lee, K.H. Park, J.H. Moon, Change in the content of phenolic compounds and antioxidant activity during manufacturing of black raspberry (Rubus coreanus Miq.) wine, Food Sci. Biotechnol. 22 (2013) 1237-1244.

[10] C.S. Ku, S.P. Mun, Optimization of the extraction of anthocyanin from Bokbunja (Rubus coreanus Miq.) marc produced during traditional wine processing and characterization of the extracts, Biores. Technol. 99 (2008) 8325-8330.

[11] B.T. Kang, D.H. Kwon, W.J. Choi, S.H. Kim, D.C.Park, Antioxidant and antiviral activities of polyphenolics in plum wine, Korean. Food Preser. 15 (2008) 891-896.

[12] G. Barbosa-Canovas, J. Fernandez-Molina, S. Alzamora, M. Tapia, A. Lopez-Malo, J. Chanes Welti, Technical manual FAO agricultural services bulletin 149, Food And Agriculture Organization Of The United Nations, Rome, 2003, p. 3.

[13] M.E.S. Oliveira, L. Pantoja, W.F. Duarte, C.F. Collela, L.T. Valarelli, R.F. Schwan, D.R. Dias, Fruit wine produced from cagaita (Eugenia dysenterica DC) by both free and immobilized yeast cell fermentation, Food Res. Int. $\mathbf{4 4}$ (2011) 2391-2400.

[14] OIV Compendium of international methods of wine and must analysis. Paris, France: Organisation Internationale de la Vigne et du Vin, 2009.

[15] D. Gođevac, V. Tešević, V. Vajs, S. Milosavljević, M. Stanković, Antioxidant properties of raspberry seed extracts on micronucleus distribution in peripheral blood lymphocytes, Food Chem. Toxicol. 47 (2009) 2853-2859.

[16] V. Katalinic, M. Milos, D. Modum, I. Music, M. Bodan, Antioxidant effectiveness of selected wines in comparison with (+)-catechin, Food Chem. 86 (2004) 593-600 .

[17] M.S. Blois, Anioxidant determinations by the use of a stabil free radical, Nature 181 (1958) 1199-1200.

[18] S. Gorjanović, M. Novaković, N. Potkonjak, D. Sužnjević, Antioxidant activity of wines determined by a polarographic assay based on hydrogen peroxide scavenge, J. Agr. Food Chem. 58 (2010) 4626-4631.

[19] J. Woraratphoka, K.O. Intarapichet, K. Indrapichate, Phenolic compounds and antioxidative properties of selected wines from the northeast of Thailand, Food Chem. 104 (2007) 1485-1490. 
[20] H. Tanner, H. Brunner Getränke-Analytik. Verlag Heller Chemie-und Verwaltungsgesellschaft $\mathrm{mbH}$, Schwabisch Hall, Scheinfeld, 1979, p. 24.

[21] C.L. Céspedes, M.V. Morales, J.G. Avila, M. El-Hafidi, J. Alarcón, OP. López, Phytochemical profile and the antioxidant activity of Chilean wild blackberry fruits, Aristotelia chilensis (Mol) Stuntz (Elaeocarpaceae), Food Chem. 119 (2010) 886-895.

[22] G. Cao, E. Sofic, L.R. Prior, Antioxidant and prooxidant behavior of flavonoids: Structure-activity relationships, Free Radicals Bio. Med. 22 (1997) 749-760.

[23] F. Tomás-Barberán, M. Gil, P. Cremin, A. Waterhouse, B. Hess-Pierce, A. Kader, HPLC-DAD-ESIMS analysis of phenolic compounds in nectarines, peaches and plums, J. Agr. Food Chem. 49 (2001) 4748-4760.

[24] B. Levaj, V. Dragović-Uzelac, K. Delonga, K. Kovačević Ganić, M. Banović, D. Bursać Kovačević, Polyphenols and volatiles in fruits of two sour cherry cultivars, some berry fruits and their jams, Food Technol. Biotech. 48 (2010) 538-547.

[25] W. Zheng, S.Y. Wang, Oxygen radical absorbing capacity of phenolics in blueberries, cranberries, chokeberries, and lingonberries, J. Agr. Food Chem. 51 (2003) 502-509 .

[26] H. Stohr, K.Herrmann, The phenolics of fruits. VI. The phenolics of currants, gooseberries and blueberries. Changes in phenolic acids and catechins during development of black currants, Z. Lebensm. Unters. F.A. 159 (1975) 31-37.

[27] M.A. Awad, A. de Jager, Flavonoid and chlorogenic acid concentrations in skin of Jonagold and Elstar apples during and after regular and ultra low oxygen storage, Postharvest Biol.Tec. 20 (2000) 15-24.

[28] S. Häkkinen, M. Heinonen, S. Kärenlampi, H. Mykkänen, J. Ruuskanen, R. Törrönen, Screening of selected flavonoids and phenolic acids in 19 berries, Food Res. Int. 32 (1999) 345-353.

[29] J.J. Macheix, A. Fleurit, J. Billot, Fruit phenolics, CRC Press, Boca Raton, FL, 1990.

[30] S.F. Price, P.J. Breen, M. Vallado, B.T. Watson, Wine phenolic responses to cluster sun exposure, ASEV Tech. Abstr. 1994, p. 4.

[31] S. de Pascual-Teresa, C. Santos-Buelga, J.C. Rivas-Gonzalo, Quantitative analysis of flavan-3-ols in spanish foodstuffs and beverages, J. Agr. Food Chem. 48 (2000) 5331-5337.

[32] M. Pantelić, D. Dabić, S. Matijašević, S. Davidović, B. Dojčinović, D. Milojković-Opsenica, Ž. Tešić, M. Natić, Chemical characterization of fruit wine made from oblacinska sour cherry, Sci. World J. 2014, Article ID 454797.

[33] I.C.W. Arts, B. van de Putte, P.C.H. Hollman, Catechin Contents of Foods Commonly Consumed in The Netherlands. 1. Fruits, Vegetables, Staple Foods, and Processed Foods, J. Agr. Food Chem. 48 (2000) 1746-1751.

[34] J.M. Koponen, A.M. Happonen, P.H. Mattila, A.R. Torronen, Contents of anthocyanins and ellagitannins in selected foods consumed in Finland, J. Agr. Food Chem. 55 (2007) 1612-1619.
[35] C. Türkben, E. Sarıburun, C. Demir, V.Uylaşer, Effect of freezing and frozen storage on phenolic compounds of raspberry and blackberry cultivars, Food Anal. Methods 3 (2010) 144-153.

[36] A.S. Meyer, J.L. Donovan, D.A. Pearson, A.L. Water house, E.N. Frankel, Fruit hydroxycinnamic acids inhibit human low-density lipoprotein oxidation in vitro, J. Agr. Food Chem. 46 (1998) 1783-1787.

[37] S.H. Häkkinen, S.O. Kärenlampi, I.M. Heinonen, H.M. Mykkänen, A.R. Törrönen, Content of the flavonols quercetin, myricetin, and kaempferol in 25 edible berries, J. Agr. Food Chem. 47 (1999) 2274-2279.

[38] U. Justesen, P. Knuthsen, T. Leth, Quantitative analysis of flavonols, flavones, and flavanones in fruits, vegetables and beverages by high-performance liquid chromatography with photo-diode array and mass spectrometric detection, J. Chromatogr, A 799 (1998) 101-110.

[39] C.V. De Whalley, S.M. Rankin, J.R.S. Hoult, W. Jessup, D.S. Leake, Flavonoids inhibit the oxidative modification of low density lipoproteins, Biochem. Pharmacol. 39 (1990) 1743-1749.

[40] A. Negre-Salvagyre, R.Salvagyre, Quercetin prevents the cytotoxicity of oxidized low-density lipoproteins by macrophages, Free Radicals Bio Med. 12 (1992) 101-106.

[41] M.G.L. Hertog, E.J.M. Feskens, P.C.H. Hollman, M.B. Katan, D. Kromhout, Dietary antioxidant flavonoids and risk of coronary heart disease: the Zutphen Elderly Study, Lancet 342 (1993) 1007-1011.

[42] M.G.L. Hertog, P.C.H. Hollman, B.Van de Putte, Content of potentially anticarcinogenic flavonoids of tea infusions, wines, and fruit juices, J. Agr. Food Chem. 41 (1993) 1242-1246.

[43] M.J. Laughton, P.J. Evans, M.A. Moroney, J.R.S. Hoult, B. Halliwell, Inhibition of mammalian 5-lipoxygenase and cyclo-oxygenase by flavonoids and phenolic dietary additives: relationship to antioxidant activity and to iron ion-reducing ability, Biochem. Pharmacol. 42 (1991) 1673-1681.

[44] A.S. Meyer, M. Heinonen, E.N. Frankel, Antioxidant interactions of catechin, cyanidin, caffeic acid, quercetin, and ellagic acid on human LDL oxidation, Food Chem. 61 (1998) 71-75.

[45] J.A.N. Laranjinha, L.M. Almeida, V.M.C. Madeira, Reactivity of dietary phenolic acids with peroxyl radicals: antioxidant activity upon low density lipoprotein peroxidation, Biochem. Pharmacol. 48 (1994) 487-494.

[46] N. Pellegrini, M. Serafini, B. Colombi, D.D. Rio, S. Salvatore, M. Bianchi, F. Brighenti, Total antioxidant capacity of plant foods, beverages and oils consumed in Italy assessed by three different in vitro assays, J. Nutr. 133 (2003) 2812-2819.

[47] H.P. Vasantha Rupasinghe, S. Cleggb, Total antioxidant capacity, total phenolic content, mineral elements, and histamine concentrations in wines of different fruit sources, J. Food Compos. Anal. 20 (2007) 133-137.

[48] E. Noumi, H. Hajlaoui, N. Trabelsi,R. Ksouri,A. Bakhrouf, M. Snoussi, Antioxidant activities and RP-HPLC identification of polyphenols in the acetone 80 extract of Salva- 
dora persica, Afr.J. Pharm. Pharmacol. 5 (2011) 966$-971$.

[49] G. Williamson, B. Holst, Dietary reference intake (DRI) value for dietary polyphenols: are we heading in the right direction? Brit. J. Nutr. 99 (2008) S55-S58.

[50] J.H. Jeong, H. Jung, S.R. Lee, H.J. Lee, K.T. Hwang, T.Y. Kim, Anti-oxidant, anti-proliferative and anti-inflammatory activities of the extracts from black raspberry fruits and wine, Food Chem. 123 (2010) 338-344.

[51] R.L. Prior, G. Cao, A. Martin, E. Sofic, J. McEwen, C. O'Brien, N. Lischner, M. Ehlenfeldt, W. Kalt, G. Krewer, C.M. Mainland, Antioxidant capacity as influenced by total phenolic and anthocyanin content, maturity, and variety of vaccinium species, J. Agr. Food Chem. 46 (1998) 2686-2693.

[52] M.N. Mitić, M.V. Obradović, S.S. Mitić, A.N. Pavlović, J.LJ. Pavlović, B.T. Stojanović, Free radical scavenging activity and phenolic profile of selected serbian red fruit wines, Rev. Chim-Bucharest 64 (2013) 68-73.

[53] J.E. Kinsella, E. Frankel, B. German, J. Kanner, Possible mechanisms for the protective role of antioxidants in wine and plant foods, Food Technol.-Chicago. 47 (1993) 85-89.

\section{IZVOD}

\section{FENOLNI PROFIL NEKIH VOĆNIH VINA I NJIHOVA ANTIOKSIDATIVNA SVOJSTVA}

Uroš D. Čakar ${ }^{1}$, Aleksandar V. Petrović ${ }^{2}$, Marijana B. Živković ${ }^{3}$, Vlatka E.Vajs $^{3}$, Miodrag M. Milovanović ${ }^{4}$ Jiri Zeravik $^{5}$, Brižita I. Đorđević ${ }^{1}$

${ }^{1}$ Univerzitet u Beogradu, Farmaceutski fakultet, Vojvode Stepe 450, Beograd, Srbija

${ }^{2}$ Univerzitet u Beogradu, Poljoprivredni fakultet, Nemanjina 6, Beograd-Zemun, Srbija

${ }^{3}$ Univerzitet u Beogradu, Institut za hemiju tehnologiju i metalurgiju, Njegoševa 12, 11000, Beograd, Srbija

${ }^{4}$ Masaryk University, Faculty of Science, Brno, Czech Republic

${ }^{5}$ Masaryk University, CEITEC - Central European Institute of Technology, Brno, Czech Republic

(Naučni rad)

Antioksidansi polifenolne strukture su široko rasprostranjeni $u$ prirodi $i$ to pogotovo u voću i proizvodima od njega. Zbog toga je u različitim voćnim vinima ispitivan sadržaj i sastav pojedinih polifenolnih jedinjenja, ali i ukupni antioksidantni potencijal tih vina. Fenolna jedinjenja su razdvojena reverzno-faznom (RF) HPLC tehnikom dok je njihov sadržaj određen pomoću masenog spektrometra sa trostrukim kvadrupolnim (TQ) analizatorom koji je pratio specifične prekursorprodukt prelaze (tzv. MRM mod). Antioksidativna aktivnost je praćena spektrofotometrijskim metodama: DPPH, FRAP i Folinovom metodom. Za proizvodnju voćnih vina su primenjene četiri vrste bobičastog voća (malina, kupina, aronija, borovnica), jedno jabučasto (jabuka) i jedno koštunjavo (višnja). Vina su proizvedena postupkom mikrovinifikacije bez i sa dodatkom šećera $u$ dezintegrisano voće pre fermentacije. Povećan nivo alkohola u vinima je uticao na povećanje sadržaja fenolnih jedinjenja $u$ analiziranim uzorcima zbog poboljšanja uslova ekstrakcije. Proizvedena vina su konzervisana dodatkom $\mathrm{SO}_{2}$ koji svojim antioksidantnim dejstvom ometa određivanje antioksidativne aktivnosti koja potiče od fenolnih jedinjenja. Da bi se ovo izbeglo napravljena je korelacija u okviru FRAP metode. Voćna vina su bogat izvor jedinjenja koja pokazuju pozitivan uticaj na ljudski organizam. U zavisnosti od vrste voća različita polifenolna antioksidativna jedinjenja su preovladavala u uzorcima vina.
Ključne reči: Voćna vina • Fenolna jedinjenja • Antioksidativna aktivnost • $\mathrm{DPPH} \bullet \mathrm{FRAP} \bullet \mathrm{RF} \mathrm{HPLC}-\mathrm{TQ}$ 